\title{
The Men Who Would Not March: The Surrender of Concordia, Namaqualand, April 1902
}

\section{A.G. Von Zeil \& David G. Thomas}

To cite this article: A.G. Von Zeil \& David G. Thomas (2011) The Men Who Would Not March: The Surrender of Concordia, Namaqualand, April 1902, South African Historical Journal, 63:2, 234-250

To link to this article: http://dx.doi.org/10.1080/02582473.2011.567292

\section{册 Published online: 30 Jun 2011.}

Submit your article to this journal $\sqsubset x$

山 Article views: 66

a

View related articles \lceil 


\title{
The Men Who Would Not March: The Surrender of Concordia, Namaqualand, April 1902
}

\author{
A.G. VON ZEIL AND DAVID G. THOMAS* \\ University of Cape Town, South Africa and University of New South Wales, Australia
}

\begin{abstract}
Those texts which have paid any attention to the surrender of the copper mining centre of Concordia in Namaqualand to General Smuts in April 1902, invariably blame this 'disgrace' on the cowardice of the elderly commandant, Captain F. Phillips, manager of the Concordia mine. Using documents retrieved from the South African National Archives, the authors argue that in fact the main reason for the surrender was a mutiny by the 100 -odd coloured members of the Town Guard, who defied an order to abandon Concordia and march to O'okiep, since that would have meant leaving their families at the mercy of the Boers. However, the Town Guard had little chance of holding Concordia and when Smuts offered to spare it from destruction in exchange for its surrender, Phillips accepted. It is argued that this decision was commonsensical rather than cowardly. In advancing an alternative narrative to that of 'cowardly capitulation', the article also emphasises the unique nature of the Concordia mutiny as an act of resistance to what today would be considered white racism.
\end{abstract}

Key words: Anglo-Boer War; Smuts, General J.C.; Namaqualand; Concordia; O’okiep; Phillips, Francis; Shelton, Hon Lt. Col. W.A.D

General Smuts took his men against Concordia... The garrison delayed and was captured... Not a shot was fired and the surrender was in disgraceful circumstances which caused an outcry against Captain Phillips... Colonel Shelton considered that he should hang as a traitor to his country and King .... Kieran, B. The Defence and Relief of Ookiep, Cape Colony, 4 April to 4 May, 1902. ${ }^{1}$

\section{Introduction}

The surrender of Concordia alluded to by Kieran occurred in April 1902 during the last major action of the Anglo-Boer War, the invasion of Namaqualand by 1200 Boers under General J.C. Smuts. Kieran was not the first to denounce the capitulation in strong terms:

*Email: dg.thomas@unsw.edu.au

1. B. Kieran, The Defence and Relief of O'okiep Cape Colony 4 April to 4 May 1902: Freedom, Franchise and Disillusionment (Hong Kong, 1995), 51. 
almost a century earlier, the British Director of Military Intelligence had called it 'the most disgraceful act of the war' ${ }^{2}$ on the grounds that its commandant, Captain F. Phillips, ${ }^{3}$ had surrendered without a shot of being fired. Other historians who have mentioned this incident such as Smalberger, ${ }^{4}$ Burke $^{5}$ and Kotzé, ${ }^{6}$ invariably refer to this total lack of resistance, the implication of which was most strongly spelled out by Hancock when he wrote: 'The officer was a coward and he surrendered'?

A set of British War Office documents retrieved from the South African National Archives, ${ }^{8}$ called the 'Concordia Papers' for the purposes of this article, throw new light on this incident. Among the noteworthy inclusions is a handwritten report penned by the Captain F. Phillips referred to by Kieran, to recount his version of the circumstances leading to the surrender. This report seems to have been written to justify his conduct to a Court Martial held on 23 June 1902. ${ }^{9}$ This, together with two further lengthy reports, one printed $^{10}$ and one in typescript, ${ }^{11}$ made by Phillips to the Namaqua Copper Company which owned the mines in Concordia, provide an alternative narrative to that of both the British Army and of historians such as Kieran, Kotzé and Burke.

The Concordia Papers indicate that rather than being disgraceful, this incident was arguably one of the most remarkable of the South African war since it was largely caused by a mutiny of the coloured ${ }^{12}$ Town Guard, 'the men who would not march', against what today would be seen as a racist instruction emanating from the British Officer Commanding in Namaqualand, Hon Lt. Col. W.A.D. Shelton. Moreover, while the mutiny delivered Concordia into the hands of the Boers without a fight, it saved the village and its mines from the depredation and destruction visited on both Springbok and Nababeep (a small mining village $20 \mathrm{~km}$ to the west), after they were captured on April 1 and 3 respectively. In both places, homes and shops were vandalised and looted; in Springbok wooden furniture in the courthouse was hacked to pieces, documents and

2. W.K. Hancock, Smuts: The Sanguine Years (Cambridge: Cambridge University Press, 1962), 238.

3. As explained below, this was a mining, not a military title.

4. J.M. Smalberger, Aspects of the History of Copper Mining in Namaqualand (Cape Town: C. Struik, 1975), 98.

5. P. Burke, The Siege of O'okiep (Guerilla Campaign in the Anglo-Boer War.) (Bloemfontein: War Museum of the Boer Republics, 1995).

6. G.J. Kotzé, Die Anglo-Boereoorlog in Namaqualand, derde uitgawe (Springbok, 1999).

7. Hancock, Smuts, 269.

8. South African National Archives War Office (henceforth SANA WO) 288 Namaqua 16 September 1903 ; 9037 Part 1 Namaqua 11 September 1902; 9037 Part 1, Namaqua 11 September 1902; 8806 1(1) 28 May 1902 Surrender of Concordia; 9494A SANA 13 September 1902 Surrender Concordia; WO 9450 Namaqua 23 September 1902.

9. F. Phillips, Notes on the Action Taken by order of Col Shelton for the Protection of the Mines and Village of Concordia [Handwritten report], SANA WO 9037 Part 2, 151-159. Although this was paginated by the original author, the second set of pages numbers in these references are those which appear in the archive file. Not all the War Office files have similar page numbers.

10. F. Phillips, The Boer Raid, Namaqua Copper Company, Annual Report and Accounts to December 31, 1902, SANA WO 288.

11. F. Phillips, Extract from letters from Francis Phillips - Superintendent of the Namaqua Copper Company's Mines, Concordia, Namaqualand, Cape Colony, June 1910, SANA WO 9037, 172-173.

12. We acknowledge that the use of this word will raise hackles in several quarters. However, we wish to make it clear that these men were not black Africans but were the progeny of Khoi women and white male settlers and miners and as such, formed a distinctive ethnic group. 
records were torn and scattered over the floor and even the clock was smashed. In Nababeep not only did the Boers vandalise civilian property in the same way but the mining plant was also blasted with dynamite. Peaceful capitulation ensured that none of this happened in Concordia, although as the Concordia Papers show, long after the war ended on 31 May 1902, the surrender continued to cause reverberations in the War Office in London and also in the offices of the Secretary State of War, the Earl of Midleton, who served in the cabinet of Lord Salisbury's Conservative administration.

\section{Concordia}

Concordia was one of the settlements which had developed in central Namaqualand after the discovery by prospectors in the 1840s of rich deposits of copper in this remote area about $500 \mathrm{~km}$ north of Cape Town. (The indigenous Nama population had known about and, on a small scale, exploited these deposits for hundreds of years previously.) The largest town was O'okiep, which in 1900 had a population of 6000 ; the mining operation here was owned by the large and wealthy Cape Copper Company. ${ }^{13}$ It was about $10 \mathrm{~km}$ north of the administrative capital of the area, the town of Springbok. Concordia was another $15 \mathrm{~km}$ north of O'okiep; its much smaller population of 2000 reflected the smaller size of the mine owned by the Namaqua Copper Company (NCC) which, however, was very profitable; according to Smalberger it produced $400 \%$ in dividends for its shareholders between 1888 and $1928 .{ }^{14}$

After the proclamation of martial law in the Cape Colony in January 1901, steps were taken to protect the considerable economic assets represented by the Namaqualand copper mines. The main defence effort was concentrated in O'okiep, the $8 \mathrm{~km}$ perimeter of which was fortified by 13 blockhouses with both inner and outer defensive lines protected by barbed wire entanglements. ${ }^{15}$ A number of British regular soldiers, 110 in all, stiffened the 1000 -strong fighting force, at least 600 of whom were coloured employees of the mine, the remainder (about 250 men) being white employees; together these two groups had been formed into the No. 1 Company of the Namaqua Town Guard Battalion (NTGB), the armoury of which included a 9-pounder field gun and a maxim gun. ${ }^{16}$ A military headquarters was established early in 1901 in O'okiep under the command of Hon Lt. Col. Shelton, a career officer of the $3^{\text {rd }}$ Royal West Surrey regiment.

Concordia in contrast had practically no defences apart from two blockhouses on koppies near the village. ${ }^{17}$ The only defenders comprised the 110-strong Town Guard raised from the employees of the mine. Ninety percent of these were coloured men, while white mine officials and Concordia civilians formed the corps of officers and NCOs. ${ }^{18}$ In fact the Army never intended to hold the place, which encompassing an area of about 24 square $\mathrm{km},{ }^{19}$ would have required at least 1000 men to defend (see Figure 1). That number was available neither from the small workforce on the mine nor from

13. Smalberger, Aspects of the History of Copper Mining, .

14. Smalberger, Aspects of the History of Copper Mining, 104.

15. Shelton Report to Col. Cooper, Commanding Namaqualand Field Force. SANA WO 9450. File 8806, 3.

16. Kieran, The Defence and Relief of O'okiep, 55-56.

17. Report of S.O. on Defence Work, Concordia, SANA WO 9037 Part 1.

18. Kieran, The Defence and Relief of O'okiep, 51.

19. F. Phillips The Boer Raid, 34. 


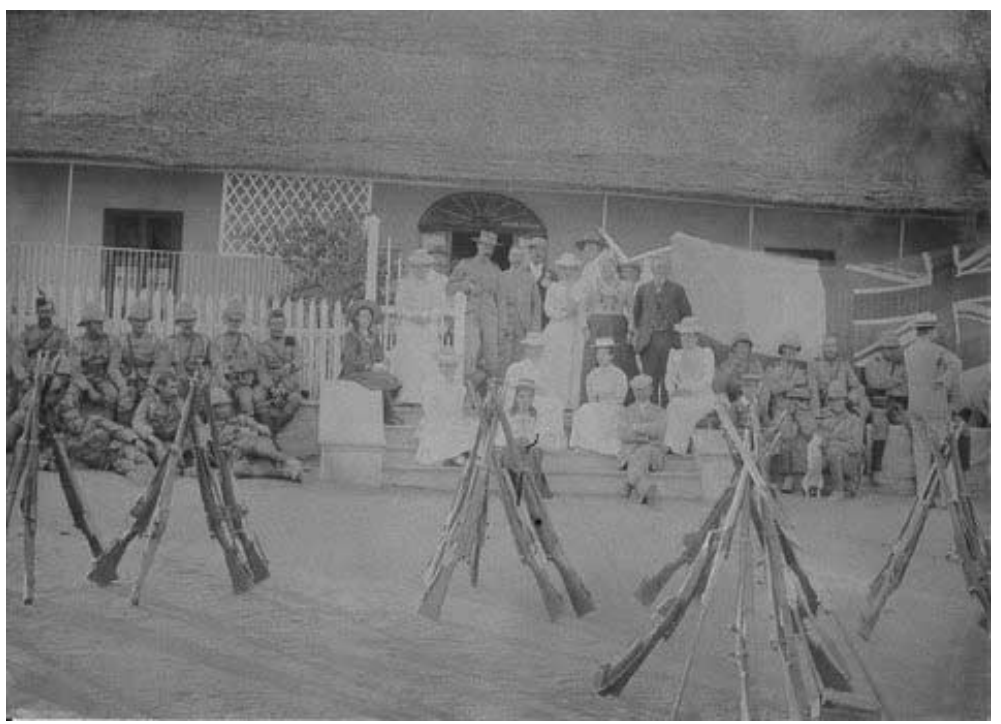

Figure 1. Captain Francis Phillips (in the dark suit) pictured together with the officer corps of the Town Guard and members of his family in Concordia sometime in 1901 or early 1902.

the over-stretched British Army. Thus the orders from the British High Command were that in the event of a Boer attack, these men were to be withdrawn into O'okiep and Concordia abandoned to the enemy. ${ }^{20}$ The Army had appointed the manager of the mine, the 68-year-old Francis Phillips, as Deputy Commandant. When the Town Guard was first raised he was also made captain of this No 5 Company of the NTGB, although finding that duty too onerous, he resigned in May 1901. He also wanted to resign the position of Deputy Commandant, but was not permitted to do so by the Army. Defending that decision, General Sir Henry Settle, Commander-in-Chief in the Cape Colony, later asserted that when Phillips' request to be relieved of his duties was not approved, 'he consented to continue on in this appointment' concluding that '... the allegation that these duties were imposed on him is unfounded' ${ }^{21}$ Settle did not try to explain the logic of that statement.

Since he played such a pivotal role in the surrender incident being recounted here, something needs to be said about Phillips. Born in Devon, England, in 1834, he had worked his way up through the ranks of the mining industry of the West Country of England and as was customary in that area, earned the title of 'Captain' when he was appointed agent of the large Prince of Wales mine in 1871. He came to Namaqualand in

20. Letter from Maj. Genl. Sir Henry Trotter to the Adjutant General to the Forces, War Office, Pall Mall, 14 October 1902, SANA WO 288.

21. Letter from Maj. Gen. Sir Henry Settle, to the Adjutant-General of the Forces, War Office, London, p. 2, SANA WO 9450 File 9037. 
$1874^{22}$ to manage the mine at Concordia, which up to that time had never been very successful. The mine's fortunes changed after Phillips discovered a huge copper lode in a hill about $2 \mathrm{~km}$ north of Concordia and persuaded the British millionaire Sir Donald Currie (owner of the Union Castle steamship line) to mobilise sufficient capital to relaunch the company in $1882 .{ }^{23}$ It thereafter became successful enough to be re-capitalised in 1888 with a sum of $£ 200000^{24}$ as the Namaqua Copper Company (NCC). ${ }^{25}$ These details indicate that since he was responsible for the mine's increasing prosperity, Phillips was likely to have had a great deal of emotional as well as career investment in the mine, something which put him at odds with Army's intention to abandon Concordia to the depredations of the Boers 'without a shot being fired'.

In fact Phillips desperately wanted his mine to be defended and expected the British Army to do so, as is indicated by the fact that, shortly before the Boer assault on the copper fields, he put to his Army superiors in O'okiep a plan for a delegation to travel to Cape Town to obtain from the British High Command sufficient soldiers to defend his mine. This was wildly impracticable; even if the manpower had been readily available, it is hard to see how it could have been organised in less than a month. Phillips asserted that he first put this plan forward in a conference in the O'okiep Army HQ on 27 March, less than a week before the Boer onslaught, and that at another conference on 1 April it was agreed that he should travel to Cape Town the following day to seek military reinforcements for the defence of Concordia. ${ }^{26}$

Phillips had no confidence that the Town Guard by itself would be able to defend the village. As already indicated, this unit was raised from among the labourers on the NCC mine. Although the conflict of 1899-1902 was ostensibly a 'white man's war', both Nasson and Wessels demonstrated that coloureds and blacks, fearful of Boer racist violence, had willingly joined similar units all over the Cape Colony after the commencement of the guerrilla phase of the war. ${ }^{27}$ That this was also the case in Concordia was confirmed by Phillips in his annual report to his company in $1903 .^{28}$ The willingness of the Concordia labourers to participate in the Town Guard would no doubt have been increased by the fact that, as asserted by Nasson, they were paid for their military duties by the Cape Copper Company. ${ }^{29}$ This may seem strange, seeing they were not working for that company, but as already noted, it was intended that their fighting capabilities would be used in O'okiep rather than in Concordia.

22. The Methodist Churchman, Vol 32, No. 9, 30 August 1920. 'Death of Captain Phillips'.

23. A. Porter, Victorian Shipping, Business and Imperial Policy: Donald Currie, the Castle Line and Southern Africa (Woodbridge: Royal Historical Society, Boydell Press, 1986), 99.

24. For what it's worth, wiki.answers.com states that $£ 1000$ in 1880 would have been worth $£ 74725$ in 2007 . Based on this calculation, $£ 200000$ in 1888 would be roughly the equivalent of $£ 14$ billion today

25. Smalberger, Aspects of Copper Mining, 98.

26. Phillips, Notes on the Action 4-5 (SANA WO 9037 Part 2, 154-155).

27. B. Nasson, Abraham Esau's War: A Black South African War in the Cape, 1899-1902 (Cambridge: Cambridge University Press, 1991), 4.

28. F. Phillips, The Boer Raid, 31.

29. Nasson, Abraham Esau's War, 54; A. Wessels, Die Militêre Rol van Swart Mense, Bruin Mense and Indiërs in die Anglo-Boereoorlog (1899-1902) (Bloemfontein: Die Oorlogsmuseum van die Boererepublieke, 1998). 
However willing the workforce of his mine was to serve in the Town Guard, Phillips believed that their training was entirely inadequate. In his reports he related that during the two weekly sessions 'of not less than one hour' conducted by a drill officer sent from O'okiep, the men were not taught much more than how to march and counter-march, present arms and on rare occasions, go out in skirmishing order. Phillips claimed that it was only at his urging that there was one shooting practice, during which each man fired five rounds at a fixed target at a range of 250 metres. No record was kept of the number of hits scored, while Phillips' request for more such exercises was refused on the grounds of shortage of ammunition. ${ }^{30}$

\section{The Attack On the Copper Fields}

The Boer invasion of Namaqualand was the culmination of an astonishing foray through the Cape Colony by General Smuts. After starting out In September 1901 with a mere 150 men, he fought his way across $1000 \mathrm{~km}$ of enemy territory from the eastern to the western Cape, adding 3000 men to his ranks by rousing rebellion among the Afrikaner population. In search of stores and bases, he then rode another $500 \mathrm{~km}$ northwards to attack the prosperous copper mining settlements, Springbok being the first town to fall. It was assaulted at $04 \mathrm{~h} 00$ on 1 April and taken after 17 hours of fighting, after which the Boers proceeded to sack and loot the town as described earlier. Between 400 and 500 men under Smuts and Commandants van Deventer, Bouwer and Maritz attacked the three blockhouses in Springbok; the remainder of the Boer force, about 600 men, seemingly moved northward, bypassing O'okiep, travelling up the road towards Concordia. This allowed the Town Guard in Nababeep, which was to the west of O'okiep, to withdraw there. ${ }^{31}$ When the Boers did occupy Nababeep a day later, they also looted and sacked it. ${ }^{32}$ The same fate would seem to have awaited Concordia.

Probably because they were regrouping and reconnoitring the area, the Boers made no more offensive moves until 4 April, when they moved on Concordia. At that stage they were ignorant of dramatic developments which had taken place in the village on 1 April. Before recounting those, it needs to be said that the chief means of rapid communication between Army headquarters in O'okiep and Phillips in Concordia was the telegraph. Although Shelton was connected to his outer defensive positions by field telephones, there was no telephonic communication with Concordia and moreover, telegraphic communication could only take place when the post office was open between $08 \mathrm{~h} 00$ and $17 \mathrm{~h} 00$ each day.

This may account for the fact that it was not until $08 \mathrm{~h} 00$ on 1 April that Shelton sent a telegram to Phillips informing him of the attack on Springbok and stating: 'I think the time has arrived for me in accordance with orders received from Head Quarters to evacuate isolated villages and concentrate my forces here.' He therefore ordered Phillips to withdraw the soldiers of his Town Guard from 'your distant blockhouses' and 'bring in ammunition

30. F. Phillips, Notes on the Action, SANA WO. 9037, Part 2, 152.

31. Report by Lt. Col W.A.D. Shelton to Col. Cooper, Commanding Namaqualand Field Force, 13 May 1902 , 7 SANA WO 9450.

32. Copy telegram from O.C. Namaqualand O'okiep [to] Deputy, Concordia, 4 April 1902, SANA WO 9450. 
and stores and concentrate your forces pending further orders from me in your village defence works'. He further ordered that 'all saddlery, clothing, boots horse shoes and anything likely to be of use to the enemy should be sent to O'okiep' ${ }^{33}$ Indicating that Shelton was ignorant of the dangers posed by the swift Boer advance, was his invitation to Phillips to ride in to O'okiep to discuss the situation. That Phillips immediately did so indicates that he too was ignorant of the immediacy of the Boer threat. Since Springbok was a mere $10 \mathrm{~km}$ south of O'okiep, not half-an-hour's ride away, it can only be surmised that both men believed that the Boers had committed their whole force to its capture and were being held up there, not realising that the bulk of the force was ready to advance northward towards Concordia.

One final extract of Shelton's $08 \mathrm{~h} 00$ telegram of 1 April to Phillips is especially important, because it had consequences which led to the most crucial episode of this whole saga. In the final paragraph Shelton had written: 'Preparation should be made to move your women and children in case it becomes necessary', adding that: 'Natives might remain with safety at any rate for the present'. ${ }^{34}$ In other words, while the white civilian population was to be evacuated to O'okiep, the coloured civilians were to be left in Concordia.

Phillips quickly responded to this telegram by riding in to O'okiep as requested. He was later to report that in his meeting with Shelton, they agreed to abide by the plan made on 27 March for Phillips to travel to Cape Town the next day, 2 April. Phillips then returned to Concordia and was probably fortunate not to have been seen or intercepted by the Boers; he later reported he had found 'great excitement prevailing', because 'the presence of the enemy had been reported'. ${ }^{35}$ Sometime during the next hour or two, Shelton seems to have become aware of the perils posed by the Boer advance. Thus at 12 noon he sent a second telegram to Phillips which in contrast to his first, had an extremely urgent tone. It read: 'You will immediately bring the whole of your Company, arms equipment and ammunition to O'okiep by marching Stop.... Move under strict service conditions with advance and rear Guards, the former well ahead and flanking files'. ${ }^{36}$

Given the rapidity and extent of the Boer advance, there can be little doubt that this telegram was sent too late. As was noted in The Times History of the War, Shelton 'should have evacuated the weak outlying positions at Springbok, Nababeep and Concordia in good time...[it] was not until April 1, when Maritz assaulted and took Springbok, that Shelton hastily ordered in the other garrisons. ${ }^{37}$ On that basis it could be argued that the second telegram cited above, should have been the first sent to Phillips on that day and that in fact it should have been sent a day or days previously. That Shelton was poorly served by his intelligence department about the Boer advance is indicated by the relaxed, non-urgent tone of the first telegram; although gathering the materiél he specified and organising the

33. Copy telkegram from O.C. Namaqualand O'okiep [to] Deputy Commandant, Concordia, 1 April 1902 , SANA 9037 Part 1.

34. Copy telegram O.C Namaqualand O’okiep [to] Deputy Commandant Concordia, Repeat to O.C. Town Guard, 1 April, SANA WO 9450.

35. Phillips, Notes on the Action 5 (SANA WO 9037 Part 2, 155).

36. Telegram from OC Namaqualand to OC No 5 Coy NTGB Concordia, SANA WO 9037 Part 1.

37. L.S. Amery, ed., The Times History of the War in South Africa, 1899-1902 (London: Sampson, Low, Marston, 1907), Vol. 5, 550. 
evacuation convoy from Concordia was bound to take several hours, there was no mention of any need for speed. The inadequacy of Shelton's intelligence is further indicated by a telegram he sent to Phillips on 4 April in which he stated that Smuts' force consisted at the most of $500 \mathrm{men}^{38}$ whereas by that stage Phillips knew that there was double that number of Boers on the copper fields. ${ }^{39}$

\section{The Mutiny of the Town Guard}

The British plan to evacuate the Town Guard, the white civilians and materiél likely to be of use to the Boers, was never carried out and on that score, Shelton blamed Phillips for disobeying his orders. In a report he wrote for an Army superior after the war he stated:

On SPRINGBOKFONTEIN being attacked and captured, on April $1^{\text {st }}$, I ordered the outlying Companies of N.T.G. Batt. [i.e. the Town Guard] to concentrate in O'OKIEP. NABABEEP at once complied [but] Deputy Commandant Phillips reported that the men of the CONCORDIA detachment said they would not leave their village. I then ordered the men to be disarmed and arms, ammunition and equipment to be sent to O'OKIEP. Instead of obeying this order when rail was open, Phillips drove in and appealed to me to allow the men to retain their arms and promising they would defend the place to the death. As by this time owing to patrols of Enemy being about, I consented, the result being that on SMUTS calling on the Garrison to surrender, Phillips took upon himself to deliver up his arms, ammunition and dynamite without firing a shot. He acted in direct disobedience of my orders and I considered his action treasonable. ${ }^{40}$

As the passage from Kieran's account quoted at the start of this article indicates, that statement formed the basis of what may be described as the 'received narrative' about the fall of Concordia ${ }^{41}$ and the excoriation of Phillips both at the time and subsequently.

Yet what emerges from the papers is that far from disobeying Shelton's orders, Phillips had made a major attempt to organise an evacuation of Concordia, recording in his handwritten report that, having heard of the formation of two large Boer encampments immediately to the south of the copper fields, on the night of 31 March he made available all his company's transport 'for the removal of stores to O'okiep'. ${ }^{42}$ In response to Shelton's telegrams of 1 April, the Town Guard was called in from the blockhouses and defensive positions and formed up ready to march when, according to Phillips, a Boer column was seen to be advancing from the southwest, the direction of O'okiep. But just as the evacuation was about to be aborted and the Town Guard ordered back to their defensive positions, it was reported that the Boer column had disappeared, seemingly making the evacuation possible. At that moment Garland, one of the officers of the Town

38. Copy telegram O.C. Namaqualand O'okiep [to] Deputy Concordia, 4 April, SANA WO 9450.

39. Phillips, Notes on the Action 9 (SANA WO 288, 159).

40. Shelton report to Col. Cooper, Commanding Namaqualand Field Force 7, SANA WO 9450.

41. Uncritically repeated by Kotzé, Die Anglo-Boere Oorlog in Namakwaland, 16-17.

42. Phillips, Notes on the Action 5, SANA WO 9037 Part 2, 155. 
Guard, returned from some mission or other. Phillips' graphic description of what followed reads:

Lieut Garland ... said ... that he was ready to go if I thought it right to do so. I stated the order had been given and must be obeyed... He again paraded his men ready for the start ... [However,] the majority refused to go unless their families could go with them. They said protect our wives and children and we will go. I told them of the serious responsibility of their action but as it was then almost dark I again ordered them to their posts and the night passed quietly. ${ }^{43}$

This mutiny was caused we suggest, by the fact that when the men were being formed up to guard the wagon train, they observed that, in accordance with Shelton's directive in his 08 h00 telegram, the convoy was for whites only. Not only would this have caused resentment but at this stage, coloureds in Concordia were likely to have been in a state of high nervousness about the Boer advance. No doubt they had heard of the massacre of coloureds by Maritz's commando at Leliefontein on January 28 and also about the sacking and looting of both Springbok and Nababeep where according to Nasson, Boers summarily shot small squads of 'native watchers'. ${ }^{44}$ Thus the coloured members of the Town Guard were unlikely to believe, as did Shelton, that 'the natives ... could remain in safety ...' and adamantly defied his order to march out of Concordia to O'okiep. As is evident from Nasson's exhaustive work on the many Town Guard units throughout the Cape, that mutiny was a unique event. The cost of the mutiny, however, was that since the Boers were by then present in force on the copper fields and likely to pounce on any large, slow-moving convoy of wagons, all hopes of evacuating Concordia in accord with the British Army plan, had disappeared.

Still, Phillips' attempt to organise an evacuation of Concordia related in his report, brings into question the charge that he had disobeyed orders made by Shelton. Moreover, the Concordia Papers raise questions about Shelton's claim that he 'ordered the men to be disarmed and arms, ammunition and equipment to be sent to O'OKIEP', because while his other orders appear in the papers, they do not contain any order that the mutineers be disarmed; in contrast, orders to Phillips given on 4 April when the surrender was imminent, that he should make the Town Guard destroy their weaponry, have been preserved. ${ }^{45}$ (That order was disobeyed, probably because Smuts gave Phillips only half an hour to respond to the ultimatum which appears below.) Moreover, even in the extensive account that Shelton prepared after the war for Colonel Cooper, the commander of the force which relieved O'okiep, there is no copy of any order to disarm the Town Guard. The only evidence that he had issued such an order is his own assertions that it was given.

Phillips' handwritten report provides a solution to the mystery of the missing order. As recorded above, it had been agreed that he would travel to Cape Town on 2 April to secure more troops to defend Concordia. However, when he went to O'okiep to catch a train leaving at $07 \mathrm{~h} 00$ for Port Nolloth, he discovered that 'in consequence of enemy along the

43. Phillips, Notes on the Action 5, SANA WO 288, 156.

44. Nasson, Abraham Esau's War, 57.

45. Copy telegram, O.C. Namaqualand O'okiep [to] Deputy Concordia, 4 April 4 pm, SANA WO 9450. 
line no train'. ${ }^{46}$ He thus went to Shelton's HQ and in the impromptu conference which ensued, Shelton probably heard of the mutiny for the first time since it had happened late on the previous afternoon after the post office in Concordia had closed and in any case, as Shelton himself reported, the Boers had cut the telegraph line to O'okiep at $16 \mathrm{~h} 47 .{ }^{47}$ Not realising this, before he left Concordia for his journey to Cape Town very early on 2 April, ${ }^{48}$ Phillips had composed a lengthy telegram reporting the mutiny, no doubt leaving it for despatch as soon as the post office opened, although again this would not have reached O'okiep because of the out-of-commission telegraph line. Thus Shelton would have known nothing about the mutiny until Phillips unexpectedly walked into his HQ on the morning of 2 April. It is very probable that on hearing of the mutiny, Shelton's immediate reaction would have been to order that the Town Guard be disarmed and their guns sent to O'okiep. If that order was given verbally, this would explain why it is absent from the written and printed record; but this also means that Phillips did not 'ride in' to beg for it to be countermanded as claimed by Shelton, whose further allegation that Phillips had promised that if allowed to retain their weapons, the Town Guard would defend Concordia to the death, is also suspect. He was later to claim that Phillips had made this promise in writing; ${ }^{49}$ however, once again neither the papers nor Shelton's extensive explanations to the officer commanding the relief force, contain any such written undertaking. Phillips himself, in his annual report to his company in 1903 said of the 'broken promise':

Only a part of the truth is told here. The question discussed between myself and Col. Shelton was the steadiness of the natives under fire. I had previously discussed this with a gentleman long resident in the country and who knows the native well, and he said:- 'I believe they will fight if led, but where are the leaders?' I repeated this to Col. Shelton, and added 'they say they will never give in, but that remains to be seen.' This is rather different from a promise to fire the last shot. ${ }^{50}$

\section{Smuts' Surrender Bargain}

Whatever the truth about this issue, there was now nothing for it but to attempt to defend Concordia with the Town Guard. They faced enormous odds; not only were these inexperienced soldiers outnumbered 10 to 1 by the battle-hardened Boers but they were also short of ammunition since, as Phillips' wrote, each man had been issued with only 200 rounds. Even an extremely slow rate of fire of one round a minute would exhaust their ammunition in a little over three hours. Phillips reports that he told Shelton during their impromptu conference on 2 April that if for no other reason, shortage of ammunition would compel the Concordia garrison to surrender. Shelton agreed to send more ammunition but his fears of this being captured en route meant it was never despatched ${ }^{51}$ (which also contradicts his assertion that the road was open on 2 April). Phillips also reported that many of the Town Guard were terrified and 'that it was with great difficulty

46. Phillips, Notes on the Action, SANA WO 9037 Part 1, 156.

47. Shelton report to Col. Cooper, 3.

48. Deputy Commandant, Concordia [to] O.C. Namaqualand, O'okiep, 2 April 1902, SANA WO 9037 Part 1.

49. Ibid. Handwritten note on copy of the $2 \mathrm{pm}$ telegram from Shelton to Phillips.

50. Phillips, The Boer Raid, SANA WO 288, 36.

51. Phillips, Notes on the Action 6-7, SANA WO 9037 Part 2, 156-157. 
that the Hottentots in our employ could be kept from throwing down their arms and hiding themselves'. ${ }^{2}$

The Boers knew nothing about these weaknesses and according to Hancock, Smuts in fact believed that Concordia was strongly verschanst ${ }^{53}$ De Kersauson de Pennendreff, a French volunteer fighting with Smuts' force, asserted that 'Concordia is omring deur ' $\mathrm{n}$ ketting koppies, wat skybaar almal deur die Britte versterk is. Die generaals was van mening dat dit ' $\mathrm{n}$ hele paar dae se veg sou kos.' That was a huge over-estimation of the strength of the defences but still, to avoid a fight he states that Maritz half-jokingly suggested to Smuts that he send the commander of Concordia an ultimatum to surrender to avoid bloodshed ${ }^{54}$ and thus Smuts, on the morning of 4 April, sent an offer to Phillips in the following terms:

Honoured Sir, If your honour is willing to surrender to me the village and mine properties of Concordia voluntarily and without force of weapons, then I am ready on my side to guarantee that all lives will be spared and all properties on the mines as well as in the village will remain undamaged and that only necessaries for my commando will be taken. If however I am necessitated to take the place by storm then I reserve a free hand in regard to all things mentioned. We await your views. ${ }^{55}$

In that ultimatum, Smuts was offering to do everything that Phillips had been striving to do to preserve Concordia and its mines. Smuts was asking a high price however, and Phillips reacted cautiously; he responded by requesting an interview with Smuts and when this was agreed to, rode out to meet him on the open veld. Smuts was accompanied by his staff and several of his commandants, a group of about 40 men in all. That led some, including Shelton ${ }^{56}$ and also Kieran ${ }^{57}$, to accuse Phillips of surrendering to a mere handful of Boers; what was not mentioned was that Smuts and Generals Ben Bouwer and Manie Maritz were among that handful. Moreover, in his conversation with Smuts, Phillips established that he and his commandants had a force of at least 1150 men which could be deployed against Concordia.

Phillips reported that Smuts proved unwilling 'to change or abate his demands in any way'. When he returned to Concordia and discussed this with his officers and the 'leading men' of the place, there was unanimous agreement that resistance to the Boers would be useless and simply lead to 'the lives of the men being worse than wasted' in Phillips' words. ${ }^{58}$ Thus the decision was taken to surrender without a shot being fired; while that was thought to be cowardly in the early twentieth century, in the early twenty-first century could it be thought of as anything but common sense?

52. Phillips, Extract from letters from Francis Phillip SANA WO 9037 Part 1, 175.

53. Hancock, Smuts, 144.

54. R. De Kersauson de Pennendreff, Ek en die Vierkleur (Johannesburg: Afrikaanse Pers-Boekhandel, 1960), 110 .

55. Handwritten copy of telegram from Phillips to Shelton, SANA WO 903 Part 2, 121.

56. Shelton report to Col. Cooper, 13 May 1902, 7, SANA WO 9450 File 8806, 3.

57. Kieran, The Defence and Relief of O'okiep, 51.

58. Phillips Notes on the Action 9, SANA WO 288, 159. 


\section{Boer Over-Estimation of Concordia's Defences}

As attested by de Pennendreff, the Boers expected a stern fight to take Concordia; what they did not realise was that the small Town Guard, with no combat experience and short of ammunition, also lacked adequate fortifications. As attested by two British officers sent to inspect the defences, ${ }^{59}$ there were only two blockhouses, poorly sited on the tops of neighbouring koppies; ${ }^{60}$ in his memoirs, Maritz remarked: 'Blokhuise was gewoonlik bo op die koppie gebou, en dit was dus baie maklik vir ons onder so 'n blokhuis in te hardloop'. ${ }^{61}$ Moreover the fall of Springbok had decisively demonstrated that it was not possible to hold a town using blockhouses alone. The only other material defence was barbed wire across the main roads into the village, ${ }^{62}$ not a major obstacle to a determined force of attackers. And yet the mere presence of the Town Guard in such defensive positions as there were in Concordia had the important effect of deceiving the Boers into thinking it was strongly fortified, thus prompting them to offer to leave the place undamaged and the people unharmed in return for the surrender.

While as suggested earlier, Phillips and his officers were condemned at the time and ever since for deciding to surrender, one question which seems not to have been asked is: what would have been gained by defending Concordia by force of arms? The answer would seem to be: very little. It is obviously phantasmagorical to think that the Town Guard could have successfully held the place; a list of the names of those who surrendered shows that they numbered only 87.63 And once the Boers had taken it, there seems little doubt that they would have sacked and looted it as they had Springbok and Nababeep, and since they were about to obtain possession of a large quantity of dynamite, quite possibly would also have destroyed the mining plant, as they had done at Nababeep. They would also have captured almost all the materiél, and ammunition (30000 rounds) they gained through the surrender and very possibly there could have been another Leliefontein-type massacre. True, the Boers had not harmed the coloured members of the Town Guard they had captured in Springbok, but these coloured soldiers had never been given the option of surrendering. On this score, General Ben Bouwer wrote in his memoirs:

... we resented the intrusion of Hottentots into the war and we not prepared to extend clemency to them. There was also is to be considered: the Hottentots had been told we would shoot any of them falling prisoners into our hands, and they would therefore refuse to be taken, [the] result [being] increased casualties on our side. If British troops elected, after being warned, to fight to the death instead of surrendering we had to put up with it; but I was not going to lose men to Hottentots on account of a mistaken notion of theirs. ${ }^{64}$

59. SANA WO 9037 Part 1. Report of S.O on Defence Work, Concordia.

60. Kieran, The Defence and Relief of O'okiep, 113.

61. M. Maritz, My Lewe en Strewe (Pretoria:, 1938), 58.

62. De Kersauson de Pennendreef, Ek en die Vierkleur, 268.

63. From Adjutant NTGB to Staff Officer, O'okep, 17 April 1902, SANA WO 9037 Part 2 (WO 145-148).

64. B. Bouwer, Memoirs of Ben Bouwer, as written by P.J. Le Riche, ed., introduction, and historical notes by O.J.O. Ferreira (Human Sciences Research Council: Pretoria, 1980), 268. 
Kotzé argues that these type of views were by no means confined to Bouwer and that other Boer commandants such as J.P. Neser were boasting of the way they had been shooting coloured prisoners out of hand. ${ }^{65}$

\section{The Cost of Concordia's Surrender}

The loss of Concordia was a serious blow to the British, although of course, their strategy all along had been to abandon it to the Boers. Not only did their capture of the village deliver into Boer hands considerable foodstuffs, stores and materiél, but also provided them with a fixed base from which they could launch their operations against O'okiep, which they cut off from the outside world and attacked continuously for the next month. This siege of O'okiep has been extensively documented and written up elsewhere ${ }^{66}$ so it will be given no attention here, except to say that the Boers were able to use the explosives stored on the Concordia mine to attack and capture some of the O'okiep blockhouses with 'dynamite bombs' fashioned out of tin cans.

Phillips stated in a second report given to the annual general meeting of his company in 1903, that he had in fact attempted to conceal his mine's stock of dynamite in an old mine shaft at Tweefontein about $2 \mathrm{~km}$ outside of Concordia and had caused a blockhouse to be erected to defend it. However, he wrote, once the Town Guard were withdrawn from the blockhouses in accord with Shelton's orders, this blockhouse was deserted and three days after taking Concordia, the Boers were able to discover the store of dynamite. ${ }^{67}$ They made extensive use of the explosives, not only using them against blockhouses at O'okiep, but also to destroy the railway line from Port Nolloth. They also tried to construct a dynamite cannon, but abandoned this project after the cannon exploded three times. Most notably, they sent a train towards O'okiep loaded with two tons of dynamite primed to explode once it had reached the centre of the town. A mounted column of 600 Boers was ready to rush in under cover of the dust and confusion caused by the dynamite explosion, ${ }^{68}$ a denouement avoided only by the train running into strands of wire strung across the line at a set of points which caused it to jump the rails and scatter the dynamite over the veld where it flamed out harmlessly. ${ }^{69}$ Massive destruction in O'okiep had been avoided by a hairsbreadth.

All of this it seemed, was due the cowardly capitulation of Concordia. Thus Phillips and his officers were arrested immediately after the siege of O'okiep was lifted on 4 May and brought before a Court of Inquiry on 6 May. But while this Inquiry found the fall of Concordia had been due to the 'due to neglect and misconduct on the part Mr Phillips...' it none the less noted that he was 'an old man totally unsuited for the position of

65. Kotzé, Die Anglo-Boere Ooorlog in Namakwaland, 24.

66. Most notably in the recent past by Kieran, The Defence and Relief of O'okiep and Burke, The Siege of O'okiep. B. Nasson gives it only passing mention in his latest volume, The War in South Africa, 1899-1902 (Capetown: Tafelberg, 2010).

67. Phillips, The Boer Raid, 35-36.

68. Shelton. Report to Col. Cooper, 13 May 1902, 7.

69. J. Henwood, Jane Henwood's Diary. The Siege of O'okiep, 31 March-21 May 1902 HIS 302 H, A.G. von Zeil, ed. (n.d. unp.) Entry for 1 May, 1902. 
Commandant with no knowledge of military affairs ...; ;0 it was in response to this critique that Settle gave the lame explanation, cited above, as to why Phillips was compelled to occupy the post of Deputy Commandant even when he wanted to resign.

Perhaps the most important aspect of the Court's judgment was that Phillips '... was not at the time [under] military law as an officer'. ${ }^{71}$ Mistakenly believing that he had been exonerated by that ruling, Phillips immediately fled $1500 \mathrm{~km}$ to Fort Beaufort in the Eastern Cape where his daughter and her husband, a local Methodist minister, were living. Shelton however, quickly despatched a military detail to follow him; they re-arrested him in Fort Beaufort and took him back under guard to O'okiep. ${ }^{72}$ While in the early twenty-first century it hardly seems worth mentioning that the members of the detail were all coloureds, in the early twentieth century that would have been interpreted as a grave slight on a white man, particularly one of Phillips' standing.

He and his fellow Town Guard officers were kept under arrest for over a month and then court martialled on 23 June, for 'gross misbehaviour in abandoning their post to the enemy'. All were found guilty and sentenced to a year in prison. That sentence however, was overturned by the British military headquarters in Pretoria on the grounds that the court martial had been 'improperly constituted', ${ }^{73}$ and was therefore ultra vires.

While the court martial proceedings themselves do not appear in the Concordia Papers, a précis is included; if it accurately reflects the proceedings, it makes the court martial look like a travesty. It seems that only Shelton's version of events was heard, excluding anything that might have been submitted by Phillips. Moreover, many of the statements are questionable; for example, the précis recorded that: 'Two or three days previous to the $4^{\text {th }}$ of April Boers had been reported in the vicinity and Mr Phillips informed Lt. Col. Shelton and asked for assistance and advice'. ${ }^{74}$ As already related, by 4 April the Boers had already captured Springbok and Nababeep and on 1 April, when Springbok was under attack, it was Shelton who had wired Phillips not once, but twice. On these grounds it could be argued that this was a kangaroo court designed to deflect blame from the British Army for failing to provide adequate defences for Concordia and also Shelton for failing to act quickly enough in response to the developing Boer attack in late March.

But while seemingly at the mercy of the British Army, Phillips had a powerful ally in the form of his Namaqua Copper Company (NCC) which had its head office in the city of London. The company's directors and managers were furious with both the British Army and the government for failing to defend Concordia and also about the way Phillips had been treated. In September 1902, almost four months after the end of the war, the company secretary sent letters containing scathing critiques of the actions of Shelton to both the

70. Proceedings of Court of Inquiry, O’okiep, 6 May 1902, By orders of Col. Cooper, SANA WO 9037 Part 1 , 66-69.

71. SANA WO 9037 Part 1, 169. The word 'under' is in parentheses because the word at that point in the original is indecipherable. However, the context makes it seem that the word 'under' is the correct one.

72. See SANA WO 9037 Part 1, Miscellaneous handwritten telegraphic traffic, From Intelligence to C.S.O., 23 May.

73. Letter from Maj. Gen. Sir Henry Settle to the Adjutant-General to the Forces No A/26320/6, SANA WO 9450 .

74. S.A. Colonial. Namaqualand Town Guard Battalion. Surrendered at Concordia 4 April 1902. Court of Inquiry O’okiep SANA WO 9037 Part 1, 63-64. 
Adjutant-General of the Army in London and to the Secretary of State for War, the Earl of Midleton. The NCC attacked Shelton for his failure to defend their mine adequately and also for his post-siege conduct, such as his appropriation of the NCC locomotive used for the dynamite attack and having it mounted on a pedestal in O'okiep as a siege memorial. He only handed it back to the NCC when ordered to do the Commander in Chief of the Cape Colony, Sir Henry Settle. Shelton was also accused of 'treating Mr Phillips with indignity', particularly with regard to the way he had sent coloured soldiers to arrest Phillips in Fort Beaufort. ${ }^{75}$

No doubt because it would have been impolitic to ignore this wealthy company (which was part of the Africa Investment Corporation presided over by Sir Donald Currie, an important member of the British Establishment), ${ }^{76}$ both the Adjutant General and the Secretary of State ordered Shelton to explain his conduct. ${ }^{77}$ Although Shelton in his long written explanations correctly blamed the Army's failure to defend Concordia on his superiors, his excuses about other points seem hardly convincing. While he argued that the locomotive had been appropriated as a trophy of war, there was no doubt that it remained the property of the NCC which is why he was ordered to hand it back to the company. The charge that Phillips was treated with indignity was denied and given the stock bureaucratic ex post facto response that this '... would have been investigated if it had been reported'. 78 There was no reference to the court martial, which seems curious seeing it was so central to the actions taken against Phillips.

Yet while Shelton's explanations satisfied the Minister and the Adjutant General, they did not satisfy the NCC, which well into 1903 continued to demand an inquiry. ${ }^{79}$ But it was unlikely that the Army would act against Shelton who had been universally praised by the highest ranking officers in the British Army and awarded the Distinguished Service Order medal by the king himself in recognition of his successful defence of O'okiep. ${ }^{80}$ Thus no action was taken and while the issue continued to be given attention, as argued above, it has been Shelton's version of events surrounding the surrender of Concordia which has been accepted without question to date.

The Concordia Papers however, indicate that if there was disgrace attached to the surrender, it had to be shared by the Army and Shelton. Firstly, Shelton deserves blame for failing to send the evacuation order to Phillips in good time; nor should it be forgotten that it was Shelton's order that the evacuation convoy be for whites only which caused the mutiny, which in turn made the evacuation impossible. Secondly, the Army and Shelton must share the blame for the arrest, pursuit and court-martialling of Phillips. To this might be added a degree of vindictiveness on the part of Shelton, who while he had learned of the annulment of the verdict in July 1902, failed to inform Phillips about this and kept him

75. Letter from the Namaqua Copper Company to the Adjutant General of the Forces, 23 September 1902 , 079/9057 (A.G.4) SANA WO 9450.

76. Porter, Victorian Business, Shipping and Imperial Policy, 152.

77. Register No. 979/0450, Minute sheet 1 SANA WO 945026 September 1902.

78. Letter to the Secretary, the Namaqua Copper Company, 19 December 1902, SANA WO 9450.

79. SANA WO 288.

80. Burke, The Siege of O'okiep, 195. 
under arrest for another month. ${ }^{81}$ He was only released after Shelton was on his way back to England. ${ }^{82}$

Yet while Phillips seems to deserve some sympathy, if any heroes emerged from this saga, it was the coloured members of the Concordia Town Guard. It was their determination to stay and defend their families that saved the town and the NCC mine twice over; firstly, had they heeded the order to march to O'okiep according to the British Army's original plan, that would have opened the way for the Boers to move into and visit on Concordia the same vandalism and looting as they had on Springbok and Nababeep.

Secondly, the continued presence of the Town Guard in the defensive positions around Concordia between 1 and 4 April, led Smuts and his generals mistakenly to believe that it was strongly fortified and therefore offer what was to prove the infinitely valuable reward of the preservation of the town, its people and the mines, in exchange for its surrender. At that time, as Nasson has most recently and comprehensively demonstrated, that although the commandants in Namaqualand did not realise it, the Boer cause was irretrievably and utterly lost. ${ }^{83}$ While Smuts had scored some successes, nothing that happened in remote and utterly un-strategic Namaqualand could have had the slightest effect on the outcome of the war and there was therefore no point in fighting to death to hold Concordia. At that stage, thoughts were better turned to post-war reconstruction and in that regard, it was of great importance that when peace came a mere two months later, the life of Concordia and its mine was ready immediately to resume on a normal basis. Phillips, his NCC company and its shareholders, as well as the white population of Concordia, all owed the Town Guard a huge debt of gratitude on that account. Today these 'men who would not march' can only be commended for their courage and determination to resist Shelton's racist 'whites only' evacuation directive and instead to stay in Concordia to defend their families.

\section{References}

Amery, L.S., ed., The Times History of the War in South Africa 1899-1902, Vol V. (Sampson Low, Marston, London, 1907).

Bouwer, B., Memoirs of General Ben Bouwer, as written by P.J. Le Riche, ed. O.J.O. Ferreira (Human Sciences Research Council: Pretoria, 1980).

Burke, P. The Siege of O'okiep (Guerilla Campaign in the Anglo-Boer War). (War Museum of the Boer Republics, Bloemfontein, 1995).

Creswicke, L. South Africa and the Transvaal War. Vol VII. The Guerilla War. From February 1901 to the Conclusion of Hostilities. The development of peace negotitations from February 23, 1901, to May 31, 1902. (London: The Caxton Publishing Company, 1905).

De Kersauson de Pennendreef, R., Ek en die Vierkleur (Johannesburg: Afrikaanse-Pers-Boekhandel, 1960).

Hancock, W.K. Smuts: The Sanguine Years 1870-1919 (Cambridge University Press, Cambridge, 1962).

81. Letter from the Namaqua Copper Company to the Adjutant General, 23 September 1902, 079/9057 (A.G.4) SANA WO 9450.

82. Note from the Adjutant General to the Forces to A.W. Outram, Secretary, the Namaqua Copper Company, 29 August 1902 079/9037 (A.G.4) SANA WO 9037 Part 2, 163.

83. Nasson, The War in South Africa, 249-251. 
Henwood, J. The Siege of O'okiep 31 March-21 May 1902, Transcribed by A.G. von Zeil. HIS 302 H, (unp.)

Kieran, B. (1995) The Defence and Relief of O'okiep Cape Colony 4 April to 4 May 1902: Freedom, Franchise and Disillusionment. (Kieran, Hong Kong, 1995).

Kotzé, G, Die Anglo-Boere Oorlog in Namakwaland. derde uitgawe (Kotzé, Springbok, 1999).

Maritz, M. My Lewe en Strewe. (Maritz, Pretoria, 1939).

Nasson, B. Abraham Esau's War: A Black South African War in the Cape. 1899-1902 (Cambridge University Press, Cambridge, 1991).

Nasson, B. The War in South Africa, 1899-1902. (Tafelberg, Cape Town, 2010).

Porter, A., Victorian Shipping, Business and Imperial Policy: Donald Currie, the Castle Line and Southern Africa (Royal Historical Society, Boydell Press, Woodbridge, 1986).

Smalberger, J., Aspects of the History of Copper Mining in Namaqualand 1846-1931. Private Publication, (Cape Town, C. Struik. 1975).

South African National Archives (SANA), WO 288 Namaqua.

SANA, WO 8806 28/5/02 Surrender of Concordia.

SANA, WO 9037 Part 1, Namaqua Copper Company.

SANA, WO 9037 Part 2, Namaqua.

SANA, WO 9450 Namaqua 23/9/02.

Wessels, A., Die Militêre Rol van Swart Mense, Bruin Mense en Indiërs in die Anglo-Boereoorlog (1899-1902) (Bloemfontein: Die Ooorlogsmuseum van die Boererepublieke, 1998). 